\title{
THE EFFECT OF USING WORD CLAP GAME ON THE VOCABULARY MASTERY
}

\author{
Putu Tressya Susanti ${ }^{1}$, Sudirman ${ }^{1}$, I Putu Indra Kusuma ${ }^{1}$ \\ ${ }^{1}$ Ganesha University of Education
}

e-mail: tressya98@gmail.com,dirman_p@yahoo.co.id, indrakusuma.eed@gmail.com

\begin{abstract}
This study aimed at investigating whether or not there was a significant effect of using Word Clap Game on the vocabulary mastery of the fifth grade students of SD Negeri 1 Banjar Jawa. The research was true experimental with Post-test Only Control Group Design. The population was the fifth grade students of SD Negeri 1 Banjar Jawa. Cluster Random Sampling was assigned to select the sample of the study. The samples were 30 students at grade 5A for experimental group and 30 students at grade 5B for control group. Those two groups were determined by lottery. The experimental group was taught by using Word Clap Game and the control group was taught by using conventional teaching technique. The data were analyzed by using T-test through SPSS program. The result of the data analysis showed that students in experimental group performed better than the students in control group. It was proven by the result of the descriptive statistics that showed the mean score of the experimental group was 89,33 while the mean score of the control group was 84,67 . The result of the t-test also showed that the value of the tobs was greater than the tcv where the tobs was 2,586 while the tcv was 1,672. Based on the findings, it was concluded that there was a significant effect of using word clap game on the students' vocabulary mastery rather than using conventional teaching.
\end{abstract}

Keywords: Word Clap Game, Vocabulary Mastery

\section{INTRODUCTION}

The most vital aspect of language that students need to master in order to communicate effectively is vocabulary. (Keshta \& Al-Faleet, 2013). Thus, it means that vocabulary is a core component of English that plays an important role to language expertise of how the students learn English. It is the essential aspects that help the students to fluent in English and can communicate well by using a varieties number of words that should be known by the students to use those words accurately.

Aslanabadli and Rasouli (2013) also point out that vocabulary plays an important role in understanding any concept in the process of learning a foreign language, it is considered as one important element that links the four language skills of speaking, listening, reading and writing altogether. The contribution of vocabulary helps the students when they want to produce sentences even in spoken or written. But, it is impossible for the students who have a limited vocabulary can produce and perform their English well. Therefore, students need to master vocabulary before they can communicate fluently by using English language.

In the learning process, the students often cannot understand what their teacher has said. Sometimes, the students are hard to catch the English expression even though it's the simple expression. This happens because the students have poor vocabulary that limits them to understand or respond the teachers' expressions. Besides that, the way of the students learning vocabulary is less effective. The lack of vocabulary happens because the 
teacher does an ordinary learning process that does not emphasize on learning vocabulary.

In the real situations, students learn vocabulary through translating new words and memorizing those words as many as possible. Then, the teacher expected that the students will remember those words and can use it later on. But, sometimes there is no following activity which makes students can test their memories. As the result, it becomes a problem that makes students difficult to learn and improve their skills level. Actually, by translating and memorizing words are not effective to make students mastering vocabulary. This may be influential, but it is not enough to help students to enrich their knowledge of vocabulary.

The phenomenon above can be seen from the teacher's activity in some school such as SD Negeri 1 Banjar Jawa which used textbook as guidance in delivering the material. The activity conducted by the teachers commonly followed by giving explanation about the material, by asking the students to answer the questions contained in the worksheet and asked the students to write new word complete with the meaning or asked directly to the students in order to make them searching for the meaning of those new words.

From the explanation above, it was concluded that the English teachers tend to use textbook as the source of learning. Teachers prefer to teach the lessons by using conventional teaching technique and sometimes use visual media, like pictures and video, or power point in the classroom. There is no following activity which is emphasized on the vocabulary mastery. As the result, the students will be hard to improve their language skills. The students often feel it difficult to memorize a number of vocabularies that must be mastered by them. If this situation happens again and again, it will be difficult to make the students fluent using English.

Certainly, the learners need something interesting that makes them easy to learn vocabulary. Students need an effective way to help them, not only to translate and memorize vocabulary but to understand it.
The use of games in teaching vocabulary is a way to make the lessons more interesting, enjoyable and effective (Klimova, 2014:1158). Playing games in the classroom can enormously increase students' ability in using language because students have a chance to use language with a purpose in the situations provided (Deesri, 2002). Besides that, games make the students remember things faster and better, because it makes an easy and relaxed atmosphere (Uberman, 1998:20). So, it means that game is good techniques which make the learning process more fun, easy, and also help the students to learn and memorizing faster and better. Game makes the students relax to learn and keep them focus to the classroom activity.

Based on the explanation above, the problems are the monotonous technique that used by the teachers to teach the students which make the students' feel bored and thinks that learned English is difficult. Thus, the writer suggests using a game as a medium to teaching vocabulary, because the writer believes that the game can be a good way to minimize the students' boredom in learning vocabulary.

Agustin (2016) who has conducted a research about game states that one of game that can be used to improve student's vocabulary mastery is by using Word Clap Game. Based on the result of her observation, Word Clap Game can be used as a strategy to improve the students' vocabulary mastery.

Theoretically, Word Clap game is one of the appropriate games that can be used as a medium to teach English. This game can help the students easy to remember the vocabulary and also build the students' confidence. Besides that, it can improve students' vocabulary also make the students enjoy the learning process without boredom. Thornburry (2002:102) states that Word Clap game is a game that played by group of students and uses clap which collaborate with the words.

Empirically, Word Clap game has not been tried in some areas in Indonesian school especially in Bali. This will be a good reason for the writer to try and apply this game in one of school in Bali in order to know the 
effect of this game in students' vocabulary mastery. Moreover, this game already applied by some researcher in other areas and it can give a good result to improve the student's vocabulary mastery. Therefore, Word Clap game will be tried in one of school in Bali named SD Negeri 1 Banjar Jawa.

SD Negeri 1 Banjar Jawa is one of schools located in the Buleleng Sub-district, precisely at Ngurah Rai Street No.45. The writer have been conduct a pre-observation and interview with some students and teacher in this school in order to know the teaching and learning process which is conducted by the teacher when teaching English. As the result, it can conclude that SD Negeri 1 Banjar Jawa used limited media learning. This school is seldom to implement such interesting media especially when teaching vocabulary.

Concerning with the success of previous research conducted by Agustin (2016) who conducted Word Clap game to teaching vocabulary and got a good result of it. Thus, Word Clap game will be tried out in SD Negeri 1 Banjar Jawa in order to test whether or not it has a significant effect to improve students' vocabulary mastery. There are two kinds of research variables. Vocabulary mastery will be the dependent variable and Word Clap game as the independent variable which is this variable will use to measure the students' vocabulary mastery. The population of this study is the students of SD Negeri 1 Banjar Jawa in fifth grade students in academic year $2017 / 2018$. For the sample, the researcher will use cluster random sampling to determine the control group and the experimental group. Then, the researcher will use lottery to determine which class will be taught using Word Clap game and which class did not using it. There are only 2 classes namely VA and VB.

\section{LITERARTURE REVIEW}

\section{Cognitive Learning Theory}

Learning is a process of acquiring knowledge through study, being taught or based on our experience. It is not only about something that we do in school or formal institution but it happens everywhere. Learning can be said as the process of increasing knowledge from one level to another level. It is the cognitive process that people use to combine new information with their prior knowledge in order to develop their mind to get something new.

Cognitive theories focus on the conceptualization of students' learning processes and address the issues of how information is received, organized, stored, and retrieved by the mind. (Ertmer \& Newby, 2013: 51). Cognitive theory emphasizes in the role of environmental conditions in facilitating the learning process such as giving explanation, demonstrations, illustrative example and other to guiding students in learning process. Cognitive processes include perception, recognition, imagining, remembering, thinking, judging, problemsolving, conceptualizing, and planning.

Cognitivism theory emphasized on making knowledge meaningful in order to help the students organize and relate new information to the students' prior knowledge. Information is transformed or processed as it passes from one stage of memory to the next. It happens in the way students learning about new information where they need time to process some information and find out the meaning of that information itself. This theory addresses how as children grow, their brains likewise mature, leading to advances in their ability to process and respond to the information they received through their senses.

\section{Notion of vocabulary}

Graves in Mukoroli (2011:6) defines vocabulary as the entire stock of words belonging to a branch of knowledge or known by an individual. He also states that the lexicon of a language is its vocabulary, which includes words and expressions.

Richards and Renandya stated that vocabulary is a core component of language proficiency and provides much of the basis for how well learners speak, listen, and write. It means that, Vocabulary is a basic foundation of a language. It is a core component to communicate, self-expression, and interpretation. Besides that, it is also the essential aspect that helps the students to communicate fluently by using a varieties number of words. 
Furthermore, Tarigan in Syamsi (1998:15) also stated about the importance of vocabulary in language learning. He states that language skill mostly depends on the mastery of vocabulary. Therefore, the more vocabulary is mastered, the bigger possibility is that someone can skillfully use the language itself.

\section{Teaching Vocabulary}

Teaching and learning activities is something that can't be separated. As stated by Ahmadi, Ismail and Abdullah (2012:187) that vocabulary learning is a difficult process, because students need to be motivated in vocabulary learning, engage in vocabulary instruction, and meet vocabulary learning standards to pursue the required accomplishment.

Cameron (2001:79) also stated that, learning a word takes a long time and many exposures to the word used in different situations. Furthermore, $\mathrm{He}$ also adds "Schooling has a major impact on how children's knowledge and vocabulary develops because it introduces them to formal logical thinking. As they move through school, so they learn how to sort things into sets, how to classify and label sets according to characteristics, how to compare and contrast categories." Thus, it means that learning English through school is one of a good way which gives a good impact to develop children's knowledge about vocabulary. Students can learn and expand their understanding toward vocabulary in the teaching and learning process.

\section{Kinds of Vocabulary}

Behlol as cited in Achmad (2013) stated that vocabularies can be divided into passive vocabularies and active vocabularies. The passive vocabulary consists of the words that the students may recognize and understand when they occur in the context but which they cannot produce or use correctly in different context. While active vocabularies consists of the words which the students understand, recall, write with the correct spellings, pronounce them correctly, and use constructively in speaking and writing.
Meanwhile, Thornbury (2002: 3) stated that English word fall into eight different word classes. They are: noun, pronoun, verb, adjective, adverb, preposition, conjunction, and determiner.

\section{The Nature of Game}

According to Martinson and Chu in TalakKiryk (2010:4), "Games are effective tools for learning because its offer students a hypothetical environment in which they can explore alternative decisions without the risk of failure. Thought and action are combined into purposeful behavior to accomplish a goal. Playing games teaches us how to strategize, to consider alternatives, and to think flexibly."

In line with the previous concept, Wang, Shang and Briody (2011) stated that game is a useful tool in improve children's vocabulary acquisition naturally as they would be normally achieved through play. Moreover, they also add that games are workable because they can easily attract the attention of students, thus influencing student motivation and enhancing English ability.

By applying game in the learning vocabulary, it will make students easier to draw their own understanding from their experiences. Furthermore, games make students focus and enjoy the learning process thus it can influencing students' emotion and make them motivated to improve their ability. Game also allowed the students to learn from their mistakes even from their friends.

\section{Word Clap Game}

Word Clap game is a game that played by group of students and uses clap which is collaborate with the words. Students stand or sit in a circle, and following the teacher's lead, maintain a four-beat rhythm, clapping their hands on their thighs three times (one-twothree...) and then both hands together (four). The idea is to take turn, clockwise, to shout out a different word from pre-selected lexical set (for example, fruit or vegetables) on every fourth beat. Player who either repeat a word already used, or break the rhythm - or saying nothing - are out and the game resumes without them, until only one player is left. The winner of this game is the last students 
that left after other students failed to mention word or the student who can mention words more than the other. (Thornburry, 2002: 102).

\section{METHOD}

This research was Quantitative research with the research design that followed the model of post-test only control group design. The setting of this research was in SD Negeri 1 Banjar Jawa. The population was the fifth grade students in academic year of 2017/2018 and for the sample of this study was 30 students in $5 \mathrm{~A}$ and 30 students in $5 \mathrm{~B}$.

There were several procedures which was conducted by the researcher to collect the data for this current study. The procedures were; first, determining the population of the study. Second, selecting the two groups randomly as the sample of the study using cluster random sampling technique. Third, deciding which group as the control group and which one as the experimental group through the lottery. Forth, preparing the research instrument for collecting data. Fifth, giving treatment to both groups differently. Sixth, administering post-test to both groups at the end of the treatment. Seventh, analysing the result of the post-test using descriptive and inferential statistical analysis. Eighth, summarizing the result of the study to determine the effect of word clap game to improve students' vocabulary mastery for Fifth grade students at SD Negeri 1 Banjar Jawa. Generally, data collection in this research used 3 techniques for collecting data such as; test, observation and documentation.

In this study, the data collected were analyzed by using two forms of statistical analysis namely; descriptive statistics and inferential statistics.

\section{FINDINGS}

Based on the data calculation and analysis, the researcher was found out that the experimental group which was treated by using word clap game achieves higher score than the score obtained by the control group which was taught by using conventional teaching. This result could be seen from mean score which was obtained from both groups where the experimental group got mean score 89.33 while the control group obtained mean score 84.67. Furthermore, it was also proven by looking at the result of inferential statistical analysis which was showed that there was significance effect of using word clap game on the students' vocabulary mastery which was supported by the significance two-tailed score .012 which is lower or less than the alpha value $(\alpha) 0.05$. Besides that, the tobs which showed the score 2.586 is also greater than tcv where the $t$ critical value (tcv) for degree of freedom (df) 58 is 1.672. Thus, it also indicate that (tobs) > (tcv) where $2.586>$ 1.672. As the result, it also proven that there was significance effect using word clap game on the students' vocabulary mastery of the fifth grade student of SD Negeri 1 Banjar Jawa in academic year 2017/2018.

Tabel 1. The result of independent sample test

\begin{tabular}{|c|c|c|c|}
\hline \multirow{6}{*}{$\begin{array}{c}\text { Mean Score } \\
\text { (Experimental) }\end{array}$} & & Interval Score & Category \\
\hline & & $93.8-100.0$ & Excellent \\
\hline & & $89.6-93.7$ & Good \\
\hline & 89.33 & $85.4-89.5$ & Average \\
\hline & & $81.3-85.3$ & $\begin{array}{l}\text { Below } \\
\text { Average }\end{array}$ \\
\hline & & $75.0-81.2$ & Poor \\
\hline
\end{tabular}




\begin{tabular}{lccc}
\hline \multirow{3}{*}{$\begin{array}{c}\text { Mean Score } \\
\text { (Control) }\end{array}$} & Interval Score & Category \\
\cline { 2 - 3 } & $88.8-95.0$ & Excellent \\
\cline { 2 - 3 } & 84.67 & $84.6-88.7$ & Good \\
\cline { 2 - 3 } & $80.4-84.5$ & Average \\
\cline { 2 - 3 } & $76.3-80.3$ & Below \\
& & Average \\
\cline { 2 - 3 } & & Po.0-76.2 & Poor \\
\cline { 2 - 3 } & & Interval Score & Category \\
\hline
\end{tabular}

Tabel 2. The result of independent sample test

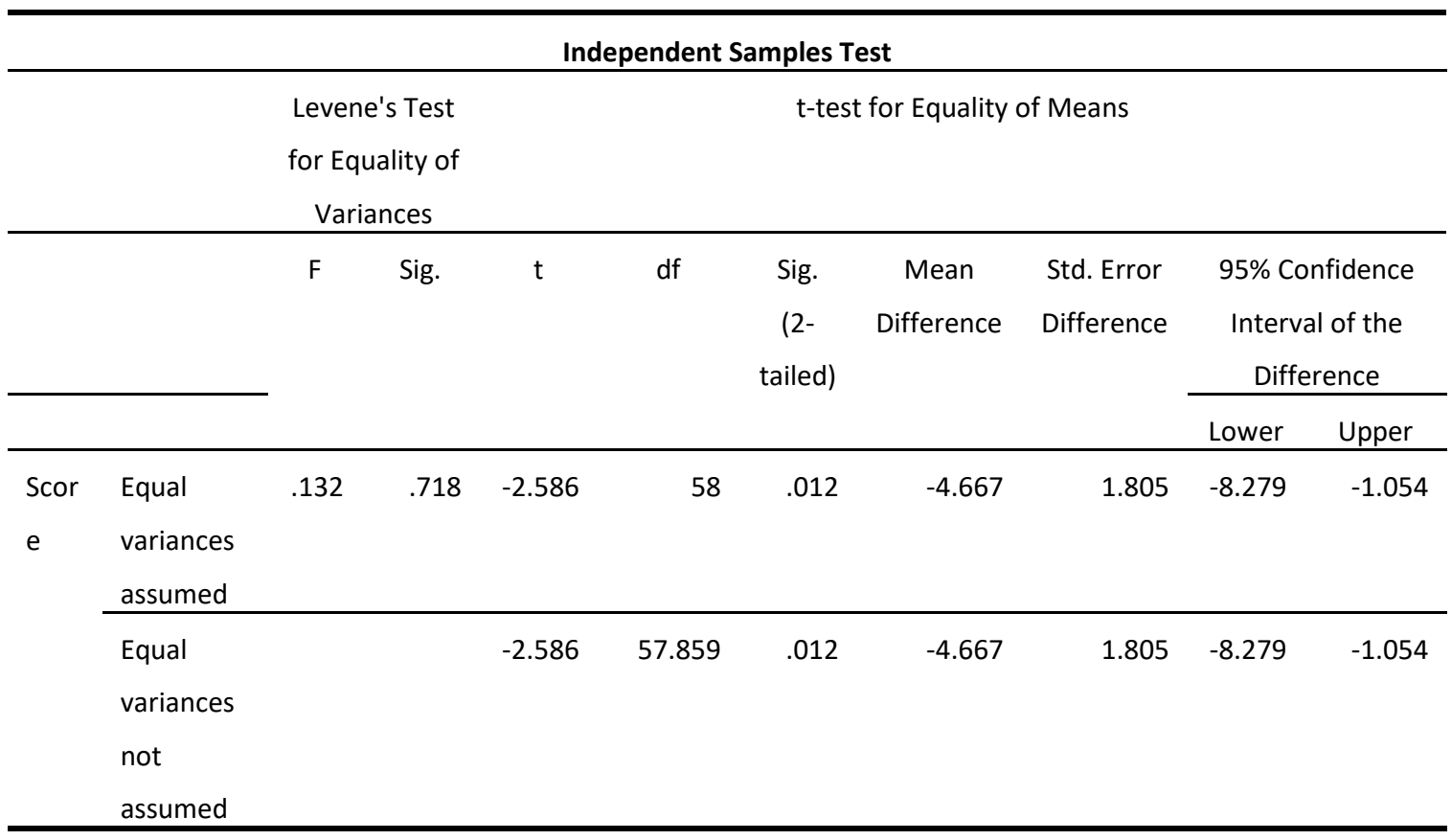

\section{DISCUSSION}

Based on the findings described above, what happens proves that the strategy used have been effective in giving significant effect on the students' vocabulary mastery. There were some points which prove that this strategy could be said as effective strategy. The effectiveness of this strategy not only supported statistically by the result of posttest score but it was also supported empirically and theoretically.

Reviewing the findings that already explained before, the effect of this strategy proved could improve the students' vocabulary mastery. As the result of posttest which was calculated descriptively and inferentially, it showed that the students experimental group' ability increase since this strategy implemented. Compared with the control group' result, it could be said that the experimental group achieve better than control group. Thus, it means that this strategy effective to applied in order to improve the students' abilities, especially in vocabulary mastery. Empirically, Agustin (2016) proved that the use of word clap game is significantly beneficial to improve students' vocabulary mastery. Furthermore, Mariyana (2016) which conducted study about word clap game in fifth grade students of elementary school also claims that word clap game can be used as an alternative media to teach vocabulary. In fact, word clap game can effective for teaching English vocabulary. 
In line with the statement above, it also proves that this strategy fits with the characteristics of students. As stated by Drachsler and Kirschner (2011) learner characteristics can be personal, academic, social/emotional and/or cognitive in nature. In this case, the meaning of students' characteristic which referenced is focus on the personal, academic and cognitive characteristics.

Related with the theory above, the findings of this study showed that during treatment the strategy used meet with the students characteristics where in the term of personal characteristics such as age, gender, or culture background of the students this strategy not meet with any problems instead of this strategy could covered every gender and culture although in young age. As well as the academic characteristics such as the educational level, more specific is the fifth grade student which is categorized as young learner and the learning goal to mastery vocabulary. During treatments given to the experimental group, the students enjoyed the learning process especially when the strategy applied. There was no problem arise even until the post-test administered. Besides that, this statement also proven by the students' score which showed significant effect toward the strategy applied. Furthermore, the students emotion also showed that they are happy during learning process in addition the students also become more confidence and active. Reciprocally, the cognitive characteristic such as intellectual skill of the students also showed positive effect such as the students more focus and pay full attention to the learning process, they easier in memorizing varieties number of vocabularies, and they could develop their intellectual skills well.

Besides explanations above, it also proved that the strategy used fits in vocabulary teaching especially for young learners where it needs to be fun and enjoyable. As stated by Cameron (2001:74) learning vocabulary is a cyclical process of meeting new words and initial learning, followed by meeting those words again and again, each time extending knowledge of what the words mean and how they are used in the foreign language. Evidently, this strategy could use as media in the teaching and learning vocabularies. Based on the advantages of this strategy which clearly proven during the treatments. This strategy was very interesting for the students and can increase the students' vocabulary. It is because this game very challenging and motivated student to memorize then mentions vocabularies as many as possible. Then, this game was easy to be applied in the classroom. Furthermore, this strategy was simple and cheap, the teacher doesn't need to buy something to be applied in a class. The students just need to clap their hands and say the words. Thus, this strategy could freely implement everywhere and every time. By knowing the advantages of this strategy, it is clearly showed that this strategy fits with the vocabulary teaching and learning where the implementation of this strategy fully focuses on vocabularies.

Teacher's Corner stated that a great way to give students meaningful opportunities to apply their learning and lower their affective filter is to make learning fun. Fun and enjoyable activity can make learning engaging and interesting, students are more willing to participate and take risks. Having fun while learning also helps students retain information better because the process is enjoyable and memorable.

Therefore, one way that could be used to make fun learning activity is by using game. Games are fun activities that promote interaction, thinking, learning, and problem solving strategies. Games have an aspect that permits the players to produce information in a short time period (Talak-Kiryk, 2010:4). Bakhsh (2016:123) explained that games are popular among children because they like to play. Through games, young learners could interact, discover, and experiment with their surroundings. He adds that games are an effective tool to teach vocabulary to young learners.

The effectiveness of game empirically proven by some researchers such as Suciati (2010), Puspitarini (2013) and Pasaribu (2015) which conducted study about game where they were already succeed to implemented 
game in teaching vocabulary and found a good result in students' vocabulary mastery. Besides that, game can also gave a good atmosphere in the classroom activity and made the learning process run well. Therefore, in this study, the strategy implemented has facilitated this activity. Thus, it becomes the reason this strategy is effective to implement.

The strategy implemented in this study is Word clap game. Thornburry (2002:102) states that Word Clap game is a game that played by group of students and uses clap which collaborate with the words. Thus, It can be said that this game played in group by remember then says the vocabularies as soon as possible along with clapping their hand. Word Clap game which was conducted in this study could be used as a medium to teach English. This game help the students easy to remember the vocabulary and also build the students' confidence. Besides that, it could improve students' vocabulary also made the students enjoy the learning process without boredom. The fact found in this research supports the statement above where the students which was taught by using word clap game showed that they were enjoy the learning process and motivated to learn English especially vocabulary. Besides the result of the post-test which showed a good result, the effectiveness of word clap game also could be seen from the students' activeness which was enthusiastic in participating the classroom activity such as answer questions or giving opinions during the learning process. In additions, the evident which showed this study effective was not only proved by theoretical and empirical data. It is also evidenced by the results of the posttest of students which calculated by using descriptive and inferential analysis.

\section{CONCLUSION}

Based on the descriptive and inferential analysis, it could be concluded that Word Clap Game gives significant effect on students' vocabulary mastery of the fifth grade students in SD Negeri 1 Banjar Jawa in academic year
2017/2018. The game was proven that is gave significant effect in experimental group.

Regard to the findings and discussions, the descriptive statistics analysis showed that the mean score of experimental group 89.33 is better rather than the control group which is obtained mean score 84.67. Furthermore, the result of the calculation of independent t-test showed the value of the tobs which showed the score 2.586 is also higher than tcv where the $t$ critical value (tcv) for degree of freedom (df) 58 is 1.672 . Thus, it could be inferred that (tobs) > (tcv) where $2.586>1.672$. ). After all, the Sig. (2-tailed) in the independent t-test table also showed .012 is lower than the alpha value $(\alpha)$ which is 0.05 . From those findings, the data implied that the experimental group which is treated by using word clap game was better than the control group. Therefore, it can be confirmed that the use word clap game is significantly effective on improving the vocabulary mastery of the fifth grade students of SD Negeri 1 Banjar Jawa in academic year $2017 / 2018$. This confirmation was proven and strengthened by the result of descriptive and inferential statistical analysis as well as the empirical and theoretical theories that support the result of this study.

\section{SUGGESTIONS}

Based on the findings and discussion of this study, the following suggestions could be taken for English teaching and learning to improve students' vocabulary mastery:

For English teachers, it is suggested to use word clap game in teaching vocabulary, since it could improve the students' vocabulary mastery. Word clap game can make the students learn vocabulary faster and better. Furthermore, it also could increase the students' motivation and activeness. Teaching vocabulary by using word clap game can make the students happy and enthusiastic.

For the students, it is recommended to implement word clap game in dratorethectescriptive and ir their vocabulary mastery. Word clap game is the best way to help the students memorizing varieties number of vocabulary in the fun and effective way. This game can be applied everywhere and every time without any cost. 
In addition, for the future researcher, hopefully this research could be one of the references for further research dealing with vocabulary.

\section{REFERENCES}

Achmad, Syarifuddin. (2013). Developing English Vocabulary Mastery through Meaningful Learning Approach. An Applied Linguistics Study at Competitive Class of Junior High School in Gorontalo City, Indonesia. International Journal of Linguistics, 5(5), 75-97. Doi:10.5296/ijl.v5i5.4454. Retrieved from www.macrothink.org/ijl

Agustin,N. (2016). Improving Students' Vocabulary Mastery Through Word Clap Game (An Experimental Research of Seventh Grade Students of SMP Muhamadiyah 06 DAU). University of Muhamadiyah Malang.

Ahmadi, M.R., Ismail, H.N., Abdullah, M.K.K. (2012). Improving Vocabulary Learning in Foreign Language Learning Through Reciprocal Teaching Strategy. International Journal of Learning and Development, 2(6), 186-201. Doi:10.5296/ijld.v2i6.2882

Alipi, Suciati. (2012). The Effectiveness of Using Hidden Word Game to Improve Vocabulary Mastery of the Seventh Grade Students of SMPN I Munjungan. Thesis, English Program, STAIN Tulungagung.

Aslanabadi, H., Rasouli, Giti. (2013). The Effect of Games on Improvement of Iranian EFL Vocabulary Knowleedge in Kindergartens. International Review of Social Sciences and Humanities, 6(1), 186-195. ISSN 2248-9010. Retrieved from www.irssh.com

Bakhsh, Sahar Ameer. (2016). Using Games as a Tool in Teaching Vocabulary to Young Learners. King Abdul Aziz University, Jeddah. Doi: 10.5539/elt.v9n7p120.

Cameron, Lyne. (2001). Teaching Languages to Young Learners. New York: Cambridge University Press.
Deesri, A. (2002). Games in ESL and EFL Class. Khon Kaen University, Thailand. Retrieved from http://iteslj.org/

Drachsler, Hendrik and Kirschner, Paul A. (2011). Learner Characteristics. Centre for Learning Sciences and Technologies (CELSTEC). Netherlands. DOI: 10.1007/978-1-4419-1428-6_347

Ertmer, P.A.,Newby, T.J. (2013). Behaviorism, cognitivism, constructivism: Comparing critical features from an instructional design perspective. Performance Improvement Quarterly 26(2), 43-71.

Frydrychová Klímová B. (2015). Game in Teaching of English. Procedia - Social and Behavioral Science, 191. Turkey, Istanbul: Academic World Education \& Research Center. 1157 - 1160, Elsevier Ltd Retrieved from http://www.sciencedirect.com/science/ article/pii/S1877042815025720

Keshta, A. S. \& Al-Faleet, F. K. (2013). The effectiveness of using puzzles in developing Palestinian tenth graders' vocabulary achievement and retention. The Islamic University of Gaza. Retrieved from http://article.sciencepublishinggroup.co m/pdf/10.11648.j.hss.20130101.16.pdf

Mariyana, Desy Elisa (2016) The Vocabulary Mastery Of The Fifth Grade Students Of SD N 1 Tumpangkrasak In Academic Year 2015/2016 Taught By Using Word Clap Game. Skripsi Sarjana thesis, Universitas Muria Kudus.

Mukoroli, Joseph. (2011). Effective Vocabulary Teaching Strategies For The English For Academic Purposes ESL Classroom MA TESOL Collection. Paper 501. Retrieved from

http://digitalcollections.sit.edu/cgi/view content. cgi?article $=1503 \&$ context $=i p p$ collection

Pasaribu, Ewin. (2015). The Effect of Using Scrabbles on Students' Vocabulary Achievement in Grade VII at SMP Sinar Harapan. A Thesis. The Faculty of 
Language and Arts. State University of Medan.

Puskás, Andrea. (2016).The Challenges and Practices of Teaching Young Learners. Univerzita J. Selyeho, Komárno. ISBN 978-80-8122-178-1.

Puspitarini, Yulinda Mukti. (2014). The Effectiveness of Using Crossword Puzzles to Increase English Vocabulary Mastery of The Second Grade Students? ? ${ }^{\mathrm{TM}}$ of SMPN 2 Ambal in The Academic Year of 2012/ 2013. English Research Aritcles. Universitas Muhammadiyah Purworejo. Retrieved from

http://ejournal.umpwr.ac.id/index.php/ scripta/article/view/1552

Richards, Jack C. and Renandya, Willy A. (2002). Methodology in Language Teaching, An Anthology of Current Practice. (New York: Cambridge University Press.

Syamsi, K. (1998). Metode Pembelajaran Kosakata. Cakrawala Pendidikan, Th. XVII, Jilid I, No. 2. Yogyakarta.

Thornbury, Scott. (2002). How to Teach Vocabulary. London: Pearson Education Limited

Talak-Kiryk, Amy. (2010). Using Game in Foreign Language Classroom. MA TESOL Collection. Paper 484.

Uberman, A. (2002). The use of games: for vocabulary presentation and revision. English department of Pedagogical University in Rzeszow, Poland.

Wang, Y.J., Shang, H.F., Briody, Paul. (2011) Investigating the Impact of Using Games in Teaching Children English. International Journal of Learning \& Development, 1(1), 128-141. Doi:10.5296/ijld.v1i1.1118 